\title{
THE ROLE OF THE BRIC IN AFRICA'S DEVELOPMENT: DRIVERS AND STRATEGIES
}

\author{
Mills Soko ${ }^{1}$ and Mzukisi Qobo ${ }^{2}$
}

\begin{abstract}
National interest still trumps friendship in international relations. The notions of solidarity that were popular among developing countries in the 1950s and the 1960s have no resonance in 21st century diplomacy, which is largely driven by commercial considerations. Many developing countries still view the advent of rising powers - some of whom were part of the Third World movement that arrayed itself to counter imperialism - as offering promise for development progress. Taking an analytic assessment of the BRIC (Brazil, Russia, India and China) countries' role in Africa's development, this article argues that such hopes are misguided. BRIC countries are not primarily driven by Africa's development concerns, but are seeking to fulfil their own commercial interests, as well as use Africa as an avenue for shoring up their international legitimacy and credibility. The article arrives at this conclusion by examining how each of the BRIC countries implements its commercial and diplomatic strategies on the African continent. South Africa is excluded from this analysis as the focus of the article is on how the non-African members of the BRICS formation pursue their diplomatic and commercial strategies on the African continent.
\end{abstract}

Keywords: BRIC countries; drivers; development; strategies; Africa.

Sleutelwoorde: BRIC-lande; dryfvere; ontwikkeling; strategieë; Afrika.

\section{INTRODUCTION}

Since 1995, the African continent has registered rapid economic growth and development against the backdrop of both a commodities' boom and expanding investment in a diverse range of sectors, from natural-resourced based industries to wholesale, retail, trade, telecommunications and manufacturing. Africa's resurgence has been evident in the surge in capital flows into the continent in the form of foreign direct investment (FDI), bank lending, as well as investor purchases of equity and debt securities. Indeed, in the seven-year period immediately preceding the global financial crisis, capital flows into Africa increased from US\$15 billion in 2000 to US\$87 billion in 2007 (Mckinsey Global Institute 2010).

\footnotetext{
1 Associate Professor, Graduate School of Business, University of Cape Town. E-mail: mills.soko@gsb. uct.ac.za

2 Associate Professor, Pan African Institute, University of Johannesburg. E-mail: mzukisi.qobo@gmail.com
} 
Moreover, there is growing consensus that Africa's future economic outlook is positive, despite the continued effects of the global economic downturn. While there is clear evidence that resource-rich African countries have served as the primary magnets of attraction for FDI to date (particularly from China and India) it is no longer just commodities that drive Africa's growth, but also the rising tide of domestic consumers and the continent's rapidly expanding middle class. The BRIC countries (Brazil, Russia, India and China) have been quick to recognise Africa's potential; and, to varying degrees, all view themselves as important partners in Africa's development. Since the formation of the BRIC grouping in 2009, these countries have all ramped up their economic involvement in Africa. Although South Africa became a member of the BRICS formation in 2010, it is, for the purpose of this article, excluded from the analysis, as the focus is on how the non-African members of the BRICS undertake their diplomatic and commercial strategies on the African continent.

This article shows that the booming presence of the BRIC countries in Africa is driven by these countries' national interest, and that the notion of a collective interest of the global South is largely a misnomer in contemporary international political economy. Notions of solidarity and friendships do not apply to countries, in the same manner as with individuals. Countries pursue partnerships or diplomatic relations in order to maximise aggregate wealth, boost their prestige, or to strengthen their relative power vis-à-vis competitors in the global system. All the BRIC states have different, even conflicting, national interests in Africa.

The article identifies the unique interests of each BRIC country in Africa, outlines the various drivers of each country's involvement on the continent, as well as the strategies employed by these countries in their respective engagements with Africa. In this context, what emerges in the analysis is that both China and, to a lesser extent, India have deeper political and cultural roots, as well as more extensive economic and diplomatic footprints in Africa than Brazil and Russia. Moreover, in the case of China and India, their strategies for engagement with African countries have often been devised as a means to counter-balance the influence of the other on the African continent.

\section{DRIVERS FOR ENGAGEMENT WITH AFRICA}

This section analyses the key drivers of the BRIC countries' political and economic engagement on the African continent. While there are certainly commonalities in these drivers across the BRICS countries, there are also clear differences and nuances across each of the countries. In this respect, the motivations for each country's involvement with Africa are imbued with a particular history, are evolving rapidly over time, and reflect the complexity of the countries' relationships with African states. 


\subsection{Economic drivers}

Undoubtedly, economic incentives form a core element of each of the BRIC countries' interests in Africa, albeit with some heterogeneity in the primacy of economics as a motivation for involvement on the continent. These countries share a common desire to gain access for their goods and services to the burgeoning consumer markets in Africa. With a combined population of over 900 million, and evidence of gradually increasing levels of household spending, Africa is viewed as a potentially profitable and largely untapped frontier for investments and exports of manufactured commodities (Cheru and Obi 2011:92). To be sure, Africa is viewed as an underdeveloped market for low-technology, but also cost-effective manufactured goods and services. Furthermore, Africa also presents an opportunity for the BRIC countries - China and India in particular - to access markets like Europe and the United States (US), due to the preferential access into those markets granted to less developed countries, especially in the case of textiles and apparels. In particular, the growth of the "middle class" has become the key narrative of Africa's resurgence. With African countries experiencing rapid economic growth, combined with rapid urbanisation, the middle classes are projected to expand, with an accompanying youth bulge in urban centres. This potentially acts as a magnet for external actors, such as China and India, to tap into this growth dynamic. Fast moving consumer goods are especially targeted, since this rising middle class will presumably consume ever-larger quantities of goods and services. Urban centres also require services infrastructure, such as banking, telecommunications, energy, and transportation, in ways that build linkages with physical infrastructure development - another important area of opportunity for the BRIC countries. Already, mining, agriculture, and infrastructure projects are at various stages of development and completion across the continent, and companies will need to provide a range of goods and services to fill the growing demand, especially for capital inputs. Add all this up, and Africa's developmental needs are likely to drive a virtuous cycle of expanding demand, employment creation, trade, and fiscal revenue generation for decades to come as the demographic dividend plays out.

Recognising this, each of the BRIC economies has devoted significant attention towards penetrating the African export markets in a way that best fits its national economic interests. In the case of China, Africa represents a ready market for Chinese manufacturers. While its imports are dominated by raw materials, China exports primarily finished products to Africa, including a range of machinery, textiles and electronic items (Sun 2014:7). In this respect, China has been quick to recognise the market potential in Africa, which it sees as a prime market for low-cost electronic and consumer goods, as well as exports of light manufacturing, agro-processing, apparel products and communications and other services (Adisu et al. 2010:4). This accentuates a static comparative advantage, 
given that African countries find it hard to break out of commodity dependence in their trading relations with China. Even though there has been a gradual shift in China's commercial foray into Africa, especially outside of the resource-rich economies, broadening out to services and manufacturing, the security of supply of natural resources remains the thrust of China's commercial diplomacy on the African continent. Consider, for example, China's trade relations with sub-Saharan African countries. While China overtook the US as Africa's single largest trading partner in 2009, with the value of trade topping US\$126,5 billion in 2010, much of the two-way trade has been skewed in China's favour. The only exceptions to this general rule are resource-rich countries, such as Angola, the Republic of Congo, the Democratic Republic of Congo, Zambia, and Equatorial Guinea, which have sustained trade surpluses (Drummond and Xue Liu 2013).

Indeed, as much as $87 \%$ of China's exports to Africa consist of equipment and machinery, textiles and clothing and other manufactured products. China is also interested in Africa's labour market. Africa boasts a large reservoir of untapped labour resources, making it an ideal location for China's labour-intensive industries (Sun 2014:6). To reform its current development model, China needs to outsource and relocate its labour-intensive industries, as well as low-skilled jobs to Africa, while developing more capital-intensive, high-tech industries within China (Sun 2014:6). The rising labour costs in China have made the need for reform increasingly urgent, and forced many Chinese manufacturing enterprises to relocate production to cheaper destinations (Ford 2013:60).

Africa also represents an important market for China's arms sales. Following the end of the Cold War, Chinese weaponry began to penetrate the African markets, replacing the Soviet Union, by offering lower priced weapons and ammunition (Masud and Faisal 2013:166). Between 2003 and 2006, Chinese arms exports to Africa were the third largest of all countries (Hofstedt 2009:84). The fact that China, "does not usually impose political, human rights, or humanitarian conditions on arms sales" has meant that Chinese-made weapons and ammunition are abundant in Africa (Vines 2007:216).

Similarly, Brazil's growing presence in Africa has been motivated by strong commercial diplomacy considerations. It is no coincidence that Brazil, for example, has been actively engaged in several countries in which both China and India have been scouring for commercial opportunities. Brazil has not been merely focusing on Lusophone countries, even though the bulk of its relations have been with these countries, in particular Angola and Mozambique. Brazil sees Africa as a key consumer market for its manufactured goods, and sees the expansion of exports of manufactured products to Africa as a means to stave off de-industrialisation. Even the Brazilian Ministry of Foreign Affairs built dedicated capabilities to backstop relations with African countries. It is suggested that in 2010, over 57\% 
of Brazilian aid went to Africa, compared to $37 \%$ that was destined for Latin America. For Brazil, the African continent is an important and growing market for exports. As Santander (2014) points out, "Beyond the official rhetoric that tries to account for the accelerated rapprochement of Afro-Brazilian relations on the basis of the historical connections and of ethnic and cultural similarities, the diplomatic activism that Brazil has engaged in towards Africa in recent years is intended to open up the African markets to Brazilian companies."

Remarkably, since Lula acceded to power in 2003, trade between Brazil and Africa, "rose from 3,5 billion euros to 18,5 billion euros in 2010" (Santander 2014). Brazilian exports to Africa, which include many agricultural products, together with manufactured and semi-manufactured goods, are far more diversified than its imports from the continent (Stolte 2012:5). As of 2012, manufactured products accounted for $42 \%$ of Brazil's total exports to Africa (Stolte 2012:9). Brazil has a growing commercial footprint on the African continent. Even so, despite Brazil's desire and efforts to grow its commercial and financial relations with Africa, trade remains relatively low and is confined to the Lusophone countries, notably Angola and Mozambique. Beyond the Lusophone countries, the country has an economic presence in countries such as Ghana, Gabon, Nigeria, Senegal, Kenya, Ethiopia, Namibia and South Africa. Companies such as Vale (mining), Odebrecht (infrastructure), Petrobas (oil) and Embrapa (agriculture) are iconic Brazilian companies that are making a mark on the continent (see Santander 2014).

For its part, India's economic interest in African countries has also been propelled by a desire to access the continent's sizeable and largely untapped export markets (Adisu et al. 2013:20). At present, India's manufactured products represent about $51 \%$ of its total exports to Africa (see Broadman 2007:83). Indian firms have been particularly keen to improve the penetration of electrical and electronic products and automobiles in African markets. According to Taylor (2012:780), the African market offers, "significant opportunities for new investments sites, export markets and capital accumulation for Indian-based interests". To be sure, the Indian government has invested heavily in key industries in Africa, such as telecoms, consumer manufacturing, automotive and resources (Walker 2014:57).

Trade and investment have also been important drivers of Russia's foray into Africa. In 2012, total trade between Russia and Sub-Saharan Africa amounted to US\$3 billion. Russia's focus has mostly been confined to tapping into markets within Africa's minerals and energy sectors. Russia has identified opportunities to, "move up the energy value chain by selling its technical expertise to developing African nations" (Investment Adviser 2009). Russian companies have also broken into such markets as science, engineering and arms. The arms trade, in particular, has been a crucial aspect of economic relations between Russia and Africa. Arms exports from Russia to the world reached US\$13 billion in 2011, with $10 \%$ of 
those destined for North Africa (especially Algeria) and 7\% to sub-Saharan Africa (Arkhangelskaya and Shubin 2013:16).

South Africa is one of Russia's key African trade partners. In 2002, bilateral trade totalled US\$138,1 million, and grew to almost US\$1 billion in 2012. Major Russian companies operating in South Africa include the Renova Group (exploration and production of manganese ore), Norilsk Nickel (production and mining of nickel), and the Evraz Group (production of vanadium and steel). Through the state-run nuclear company, Rosatom, Russia has been focusing on ramping up its supply of nuclear reactors to African countries. This includes South Africa. Rosatom is believed to be the frontrunner to supply South Africa with $9600 \mathrm{MW}$ of nuclear energy. Rosatom is also in line to construct four nuclear reactors in Egypt at 1200MW each. In March 2015, Rosatom and the Nigerian government signed a cooperation agreement for the design and construction of four nuclear reactors at a total cost of US\$20 billion. Furthermore, Ghana has concluded a cooperation agreement with Rosatom on the peaceful development of nuclear energy.

Aside from exporting their goods and services to Africa, a yearning to gain access to Africa's natural resources is another key driver of the BRIC countries' involvement on the continent. The abundance of natural resources in Africa has piqued the attention of the BRIC countries, both for their own economic interests, but also for reasons of energy security. As the BRIC countries industrialise with unprecedented speed, their fast-growing economies demand increasing supplies of oil, gas, timber and other natural resources to fuel development. Africa, with rich reserves of minerals and raw materials, is a key source of these supplies.

In the case of both India and China, in particular, Africa is critical as a source of natural resources and raw materials, especially oil. Due to its limited exposure to the world's main conflict zones, its general openness to foreign participation, and high quality, African oil supplies are of considerable strategic importance to these countries (Adisu et al. 2013:19). China became a net-crude oil importer in 1993. Today, it is the second largest consumer of oil in the world and around $25 \%$ of its oil imports come from Africa (Yates 2006:219).

Africa is regarded as a key source of natural resources to serve as inputs into production and to fuel China's energy needs, while also serving as a market for Chinese exports, all of which are key to China's continued economic growth and development (Hofstedt 2009:85; Sun 2014:1). Indeed, large-scale economic development in China is increasingly throttled by the depletion of domestic energy reserves and natural resources (Sun 2014:6), meaning that access to much-needed natural resources is a key element of China's relationship with African countries (Masud and Faisal 2013:163). At the same time, China is also attempting to reduce its dependency on the Middle East to fuel its energy needs (Masud and Faisal 2013:164). China's internationalisation strategy has balanced investments 
in the financial sector and technology acquisitions in the West with expansion into, what was in the past regarded as peripheral economies, in Africa (Zeng and Williamson 2007:96). It is heavily engaged in the African economies across energy, agriculture, finance, and telecommunication sectors.

For its part, India needs to import $90 \%$ of the crude oil and natural gas required to feed its industrial appetite (Adisu et al. 2013:19). The International Energy Agency predicts that India's oil dependence will increase from 2,1 million barrels a day in 2007 to 6,6 million barrels a day in 2030. As the world's fifth largest consumer of energy, India is keen to match its needs with Africa's growing production output. Deepening relations with Africa - especially oil-producing countries, such as Nigeria and Sudan - has been crucial to India's energy security considerations. Pradhan (2012:284) argues that India's involvement in Africa is primarily motivated by a need to secure supplies of oil and gas, and its, "foreign policy is now concerned with two major aspects of energy bases abroad: diversification and investment". In order to guarantee its energy security and shift its oil dependence away from the Organization of the Petroleum Exporting Countries (OPEC) and towards other sources, India conducts an India-Africa Hydrocarbon Conference every alternate year (Pradhan 2012:288). At present, India's current bilateral energy partnerships are mainly with the South African Development Community (SADC) countries (Ganeshan 2012:73).

In contrast to India and China, Brazil's involvement in Africa is less motivated by natural resources needs. Brazil is not reliant on imports of natural resources from Africa, as it is a natural resource-abundant country itself, with ores, oil and fuel products contributing a significant share of the country's total exports (Stolte 2012:4). Instead, the resource-based specialisation of Brazil's large-scale enterprises is central to the country's activity in the resource sectors of African countries (Stolte 2012:4). Since Brazil does not need to secure energy and resources overseas, the presence of companies, such as Petrobras, in foreign markets derives from a desire to internationalise and diversify its markets (Stolte 2012:4).

In this sense, the Brazilian state-owned oil company Petrobras and the mining company Vale are, "deeply involved in the extraction of Africa's resources", and oil and other natural resources account for almost $90 \%$ of Brazil's imports from Africa (Stolte 2013:63-64). Having operated in the oil-rich African states of Angola, Benin, Gabon, Nigeria and Senegal, Petrobras is regarded as a key actor in fulfilling the Brazilian state's ambition to secure oil supplies (Stolte 2013:64).

Akin to Brazil, accessing natural resources is not central to Russia's interests in Africa. Internationally, Russia is an important producer of minerals, oil and gas (Klomegah 2008). In 2012 alone, natural gas and oil contributed close to $30 \%$ of Russia's gross domestic product and accounted for nearly two-thirds of total exports (Mandelbaum 2014). Simply put, Russia does not have the same 
need as China, or even India, to purchase natural resources. That said, Russian companies are striving, "for better access to the mineral wealth of countries across the continent", and their deals with African members of OPEC are designed to, "get a stranglehold on Europe's natural gas supplies" (Africa Research Bulletin 2008:17972). The financial crisis of 2008 exposed the extent to which Russia relies on oil and gas to support growth, and encouraged the Russian political and business elites to look towards the abundant energy reserves available in Africa (Investment Adviser 2009).

Russian imports from Africa include, among others, manganese, chrome, nickel, zinc, lead and bauxite (Arkhangelskaya and Shubin 2013:16). More than 30 large Russian companies are involved in the development of Africa's natural resources projects. In South Africa, Russia aims to control nearly half (45\%) of South Africa's uranium enrichment market. Russia also hopes to use South Africa as a springboard from which to establish a competitive position in Africa's natural resources sector, focusing particularly on the extraction of nickel, chromium, diamonds, zinc and cobalt (Qobo 2010).

Aside from these economic considerations, the individual BRIC countries have a range of geo-political, ideological and foreign policy motivations, which are tied to their national interests, for engaging with the African continent. These motivations are discussed, in turn, below.

\subsection{Geopolitical, ideological and foreign policy drivers}

\subsubsection{China}

China, as the BRIC country most involved in Africa's infrastructure development, has the most profound national interest rooted in the continent. To identify Chinese objectives in Africa, it is crucial to understand China's core national interests, which the Chinese ruling party kept opaque until 2009. The erstwhile State Councillor, Dai Bingguo, first elucidated China's core national interests at a press conference in 2009. These were national security, sovereignty, territorial integrity, and sustained economic and social development (Xinhua 2009). Safeguarding national security and maintaining state sovereignty can be seen as a mechanism for the Chinese Communist Party (CCP) to ensure regime survival, reinforce internal stability, and continue the current political system of one-party dominance.

Owing to the absence of democratic elections, the regime in China faces a considerable challenge to preserve its legitimacy (Sun 2014:12). Internationally, recognition by foreign governments of the CCP's successful political and economic policies is regarded as a powerful reinforcement of its legitimacy at home. Domestically, the CCP's legitimacy is intrinsically tied to the birth of a "new" China 
and the reforms to the Chinese economy that have boosted per capita incomes and opened up the economy (Sun 2014:12).

In this context, seeking friends in the developing world, especially on the African continent, has become a vital pillar for strengthening credibility and legitimacy. China has crucial political interests directly embedded in Africa. Not only does the country seek to import raw materials from Africa, it also uses the continent as an arena in which to exert and grow its international influence (Gottwald and Duggan 2011:7). In a White Paper published in January 2006, China announced a series of general principles and objectives that would underpin its policy towards Africa, including sincerity, friendship and equality; mutual benefit, reciprocity and common prosperity; mutual support and close coordination; learning from each other, and seeking common development; and the "one-China principle" (People's Daily 2006).

Initiatives such as the Forum for China-Africa Cooperation (FOCAC) have diplomatic and geopolitical utility for China's wide-ranging international ambitions. Moreover, FOCAC helps China solidify a single, favourable, perspective on China for the entire continent at one go, even if such a goal is tenuous, as there remain divergent views about China across the continent. FOCAC is structured on China's terms: African countries that do not adhere to the "One-China" policy are excluded. The Forum's agenda themes also tend to reflect the Chinese interests. For example, the proposed theme for the 2015 FOCAC Summit, which was held in South Africa, encapsulates both South Africa's aspiration and the African Union's Agenda 2063, as well as the Chinese vision: Rising Together: Agenda 2063 and the Chinese Dream.

Regarding the "One-China" principle, more than six decades after the Chinese civil war, Taiwanese sovereignty and legitimacy remains a salient issue on Beijing's agenda. In this context, "the Chinese Government appreciates the fact that the overwhelming majority of African countries abide by the one-China principle, refuse to have official relations and contacts with Taiwan and support China's great cause of reunification" (People's Daily 2006). Indeed, China's steadfast adherence to its one-China principle is consistent and notable in its dealing with African states (Adisu et al. 2010:4). According to Masud and Faisal (2013:163), one of Beijing's key political objectives in Africa is to diminish recognition within Africa of Taiwan as the legitimate government of China, and to urge African countries to oppose Taiwan's participation in international institutions (Sun 2014:5).

Beijing not only aims to limit Taiwan's diplomatic influence in Africa, it is also interested in aligning its policy objectives with African states as a means to counterbalance the hegemonic influence of the West and the US in particular (Konings 2007:351). To this end, the country hopes to garner African support for its foreign policy agenda in multilateral forums (Sun 2014:3). Moreover, Africa 
matters greatly to China in terms of ideological interests. The emphasis in China's foreign policy on non-interventionism has meant that Beijing is loath to impose moral or ethical standards on African countries (Ford 2013:60). As a result, the majority (82\%) of China's oil imports from Africa come from countries with questionable human rights records (Masud and Faisal 2013:165). By emphasizing the primacy of business and adhering steadfastly to a non-interference policy, close ties with China present a compelling alternative for African countries to Western powers, whose trade and investment ties with African countries are typically conditional on good governance and other factors (Masud and Faisal 2013:167).

Finally, China has enormous security interests in Africa. In the context of ongoing political instability and conflict in parts of the continent, the exponential expansion of China's commercial interests in Africa has brought with it significant security challenges, with the result that Beijing is eager to prioritise the protection of its economic interests and personnel on the continent (Sun 2014:1). In the past, China relied largely on multilateral institutions, particularly the UN, to safeguard its interests in Africa (Sun 2014:11). However, in recent years, Beijing has adopted a considerably more self-reliant approach to protect its interests on the continent. For example, recognizing that Chinese vessels were frequently coming under attack from Somali pirates, Beijing dispatched The People's Liberation Army (PLA) to provide naval escorts for its ships through the Gulf of Aden (Sun 2014:11). Since 2008, the PLA has provided 16 fleets to escort 5300 Chinese and foreign ships, and continues to do so (Sun 2014:11). The PLA has also helped to train military personnel in 18 African countries and established exchange agreements with 25 African states (Hofstedt 2009:84). Moreover, around 1500 Chinese military personnel support seven different UN peacekeeping operations on the continent, with Chinese peacekeepers outnumbering those from all other permanent members of the UN Security Council (Sun 2014:84). In addition, China provides financial assistance to the African Union's (AU) standing army.

Although Beijing's political influence in Africa continues to expand, it is less pervasive in comparison to China's economic presence on the continent (Sun 2014:84). This is due, in part, to the greater emphasis placed on economic considerations in China's domestic and foreign policy agenda, following the decision to reform the Chinese economy and open it up to foreign investment (Sun 2014:5-6). This policy shift stems from the Chinese leadership's decision to consolidate its legitimacy and ramp up support from the Chinese population by focusing on bringing economic development to China (Sun 2014:5-6).

\subsubsection{India}

India has deep political, as well as foreign policy interests in Africa. On the continent, India has been competing with China to gain access to African markets, 
to utilise Africa's natural resources in order to secure energy security, to expand its diplomatic influence in the region, and to advance development cooperation (Cheru and Obi 2011:91). As a result, the strength of India's political ties on the continent is especially important. Many of India's political ambitions rest on them being supported by African countries in the UN, support which politicians in New Dehli are confident that they can count on, particularly with respect to India's bid to secure a permanent seat on the UN Security Council (Taylor 2012:793).

India's political ties with African countries are strengthened by New Dehli's relative geographical proximity to the continent, as well as shared experiences in their respective struggles to gain independence from colonial powers (Adisu et al. 2013:18). Mahatma Gandhi's Satyagraha movement originated in South Africa, and India was a leading international actor in the battle against apartheid in South Africa (Adisu et al. 2013:18). Furthermore, India is sympathetic to African nationalist movements, owing to its own experiences in struggling against colonialism (Mawdsley and McCann 2010:89). According to Beri (2003), India's foreign policy objectives in Africa after the Cold War can be summarised into five broad elements: promoting economic cooperation; engaging the persons of Indian origin in Africa; preventing and combating terrorism; preserving peace; and assisting African defence forces. New Delhi also sees engagement with Africa as a means to promote its political aspirations to develop India into a major power on the international stage; promote cooperation and leverage the power of developing countries in multilateral institutions; facilitate cooperation within the developing world to combat global inequality; advance multilateralism in international relations; and push for a "reconfiguration of the global governance architecture" (Beri 2003).

India has historically been an important source of investment and immigration into both East and Southern Africa, but also in West Africa (United Nations 2007:1). At a continental level, India has made a significant contribution to the New Partnership for Africa's Development by extending a US\$200 million line to fund its operations. In its Exim Bank policy of 2002-2007, India launched its "Focus Africa" programme to increase Indian exports to sub-Saharan Africa. Specific target markets are: South Africa, Nigeria, Mauritius, Kenya, Ethiopia, Tanzania and Ghana. The Indian government also provides concessional credit lines to a number of African countries like Sudan, Ethiopia, Mauritius and Seychelles (United Nations 2007:1). A further line of credit of US\$250 million was extended to the Economic Community of West African States through the Indian Exim Bank for a range of regional infrastructure projects in the fields of energy, telecommunications and railways.

At the CII-Exim Bank Conclave on India-Africa Project Partnership held in New Delhi in 2010, further pledges were made towards assisting Africa's development. These pledges included a commitment to establish 19 institutions 
aimed at developing human resources capabilities. These institutions include, among others, the Africa-India Institute of Foreign Trade; Africa-India Diamond Institute; Institute of Information Technologies; and Education Planning and Administration Institute (Freemantle and Stevenson 2010).

\subsubsection{Brazil}

Historically, Brazilian foreign and economic policies have focused on North America, Europe and South America. This changed when Lula Da Silva succeeded Henrique Cardoso as president in 2003. Lula made Africa a strategic priority and consciously included Africa in Brazil's foreign policy objectives. He recognised that if Brazil, an emerging power, was to fulfil its global ambitions it had to cement strong relations with the key regions of the world, including Africa. During his presidency, he made 12 trips to Africa and visited 21 countries, while Brazil hosted 47 visits of African leaders. Furthermore, Brazil's diplomatic missions to Africa doubled in number under his tenure. Lula's foreign minister, Celso Amorim, undertook 67 official visits to 34 African nations (Matthews 2012:24). Brazil's approach towards Africa is also grounded in a desire to gain recognition as a major power in the international system.

By engaging with Africa, Brazil seeks to gather support for its pursuit of a permanent seat on the UN Security Council (Stolte 2012:10; Stolte 2013:67), and to, "demonstrate its willingness and ability to make a contribution to the solution of global problems" (Stolte 2012:18); gain political support domestically by reconnecting to Africa; and reduce the Brazilian economy's reliance on the developed world (Ford 2013:88). These goals form part of, what Lula dubbed, a new global political and economic geography in which the developing world has a significant voice in the multipolar international system (He 2012:32). At the same time, Brazil's focus on Africa has also been borne out of a desire to create a strategic security area in the Southern Atlantic Ocean (Ford 2013:87). The current government of Dilma Rousseff, has built on Lula's legacy and emphasised "Brazil's and Africa's shared historical standing as developing countries" (Matthews 2012:24).

\subsubsection{Russia}

Moscow had not identified Africa as a significant part of its foreign policy strategy ever since the end of the Cold War, during which the US and the Soviet Union competed for favour and influence in Africa through the provision of development assistance (Klomegah 2008). However, this posture changed in 2013 when the Russian government published its Foreign Policy Concept (Arkhangelskaya and Shubin 2013:9), which stated that, "Russia will enhance multifaceted action with African states on a bilateral and multilateral basis with a focus on improving 
political dialogue and promoting mutually beneficial trade and economic cooperation and contribute to settling and preventing regional conflicts and crises in Africa."

Russia enjoys diplomatic relations with all African countries and 40 Russian embassies operate in Africa, while 35 African countries have embassies in Russia. Furthermore, Russia has representatives at the AU, as well as to the regional communities of the Southern African Development Community (SADC), East African Community (EAC) and the Economic Community of West African States (ECOWAS). Moscow's diplomatic ambitions in Africa have been evidenced by the number of African visits undertaken by the country's president, Vladimir Putin, to countries such as Egypt, Algeria, South Africa, Morocco and Libya (Arkhangelskaya and Shubin 2013:14).

In strategic terms, Russia sees its relations with Africa as crucial to its desire to promote a multipolar world and to ensure that Russia is not isolated internationally. Russia has participated actively in contributing towards peace and security in Africa, notably through participation in UN peacekeeping missions in Africa, including in countries such as the Democratic Republic of Congo (DRC), Liberia and Sudan. Even so, it can be surmised that Russia's policy towards Africa, like that of Brazil's, is nowhere near as ambitious as those of China and India. This is reflected in the limited financial commitments to the implementation of Russian foreign policy in Africa (Klomegah 2013). Today a realist approach, which is sensitive to geo-politics and balance-of-power considerations, is central to Russian foreign policy (Jordan 2010:83). This mentality contributes to the lack of attention given by the Russian leadership to the African continent, because, "Russian leaders view great power multilateralism as more about coordinated action than fostering and adhering to common norms, and their approach is more instrumental than principled" (Jordan 2010:83). That said, Russian businesses that operate overseas, including the ones in Africa, are regarded as instruments of an increasingly forceful Russian foreign policy (Africa Research Bulletin 2008).

\section{STRATEGIES FOR ENGAGEMENT}

In much the same way that many of the drivers of the BRIC countries' involvement in Africa differ from country-to-country, they have also employed different strategies to achieve their national interests on the continent. Moreover, in the case of China and India, their strategies for engagement with African countries have often been devised as a means to counter-balance the influence of the other on the African continent.

China's re-engagement with Africa has been carried out at the highest political level since the mid-1990s. This re-engagement has formed part of Beijing's "going 
global strategy". Ease of access to bank loans, simplified border procedures and preferential policies for taxation, imports and exports were introduced to support Chinese state-owned enterprises (SOEs) to move beyond China's borders (Freemantle and Stevens 2010). In the case of Africa, these measures have been actively backed up by high-level visits, which included the Chinese President, the Premier and Vice-Premier (Klomegah 2013).

Although African analysts point out that more than 770 exchange visits have taken place between China and Africa in the period 1950-2004 (see Baregu 2007:210), the presidential visit of former Chinese President Jiang Zemin to Africa in 1996 set the path for a more active political and economic interaction between Africa and China. The most prominent example of such high-level diplomacy was the hosting in Beijing of the Third Forum on China-Africa Cooperation (FOCAC) in November 2006, which was attended by 41 African heads of state (United Nations 2007:62). This was repeated in 2009 with the hosting of the Fourth FOCAC in Egypt, attended by 50 African heads of state, where China pledged more resource support towards Africa, and a doubling of development assistance in the next five years.

On a practical level, China has honed in on the reality that many African countries continue to struggle with a lack of access to capital and inadequate infrastructure (Masud and Faisal 2013:164). Against this backdrop, Chinese involvement in Africa can be regarded as "mutually beneficial" - with China gaining access to natural resources and service contracts and African countries benefiting from ready access to finance and infrastructure development (Sun 2014:8). As one explicit example of this relationship, the China Railway Group secured mining rights in the DRC using the slogan infrastructure "projects for resources" in 2008 (Sun 2014:8).

Moreover, the Chinese government, "actively promotes investment in Africa through concessional loans, commercial loans, and regular and preferential export buyer's credits" (Sun 2014:7). In turn, the flow of capital into Africa has stimulated commercial opportunities for Chinese service contractors, particularly those operating in the construction industry (Sun 2014:8). To be sure, an important condition of the financial assistance provided by China to African countries is that Chinese companies are favoured when awarding contracts for infrastructure construction projects (Sun 2014:8). Indeed, as much as $70 \%$ of these contracts are awarded to Chinese companies, many of which are state-owned; while the remaining $30 \%$ is available for domestic firms, albeit many of which engage in joint ventures with Chinese companies (Sun 2014:8).

By applying a non-intervention strategy to Africa, China is looking to provide a direct counter to the historically mercantilist and militarist approach to Africa adopted by the US (Masud and Faisal 2013:164). Owing to China's vocal opposition to colonialism, imperialism and revisionism, many African states regard China as a 
natural leader of the developing world, and see Beijing as an instrumental player in efforts to reform the unipolar international order (Masud and Faisal 2013:163). As such, Chinese and African leaders are eager to partner strategically both in order to advance economic development and shared prosperity and to reform the current global economic and political architecture (Konings 2007:351). By spreading the "Beijing Consensus", China is able to exert considerable influence over Africa, which provides Beijing with significant soft power as it looks to expand its global standing (Sun 2014:12). The building of the Confucius Institute, the offering of government scholarships, the establishment of cultural agreements and cultural exchanges, as well as the growing Sino-Africa tourism are all cited as evidence of Beijing's burgeoning soft power in Africa (Masud and Faisal 2013:168).

In contrast to China, most of India's engagement with Africa has been driven by the private sector. Indeed, India's diplomatic presence in Africa is considerably smaller than that of China. India has diplomatic missions in 26 African countries, whereas China is represented in 46 countries. Perhaps as a result, India's engagement with Africa has been somewhat different from China, both in nature and in scale. Apart from the fact that India lacks China's financial clout, much of its focus has been on infrastructure development, technical assistance and capacity building, mainly targeting areas such as roads and railways, agriculture, information and communications technology (ICT), and health. In this respect, India views Africa through the prism of its own developmental challenges and democratic value system. Its engagement with the continent is shaped by providing technical assistance where it believes it is best suited to do so, in agriculture, health, education and ICT. India places emphasis on historical and cultural relations with Africa, as well as technical capacity support. It is in this respect that it differentiates itself from China.

Recently, however, India has also begun to shift from its low-key approach and ratchet up its commercial diplomacy. In a manner not dissimilar to the Chinese form of engagement, India couples its development engagement - which comes in the form of soft loans and infrastructure development - with the commercial imperative of accessing vital resources. This change of accent took place after it unexpectedly lost an exploration bid at Angola's Block 18 to the Chinese in late 2004. The Chinese had outsmarted India's ONGC Videsh Ltd through a last minute offer of a US\$2 billion loan to fund infrastructure projects. In the same year in Nigeria, ONGC lost in similar circumstances to Korea's National Oil Company after it promised to build a gas pipeline, a shipyard, rail link and power plant for the Nigerians (Vines et al. 2009:2).

In the wake of these commercial losses, India stepped up its diplomatic relationship with Africa through a series of high-level meetings between the two sides. Apart from East Africa, where India is concentrating its investment in market- 
seeking domains in eight East African countries, the two countries that occupy pre-eminence in India's commercial strategy towards Africa are Sudan and Nigeria, both on account of their oil production. Sudan, Nigeria and the DRC absorb much of India's infrastructure financing on the African continent.

After losing the bid to the Koreans, it became clear to India that Nigeria had a strong interest in developing its infrastructure, as well as its downstream sector, and these are areas that India would have to include in its commercial bids. The country had to change its approach to suit the expectations of the host country, which, to a considerable extent, have been shaped by the "Chinese model". This prompted Sunil Mittal (NDTV 2011), India's most prominent entrepreneur, to assert that he has, "finally cracked the code of operating in Nigeria".

In the wake of a visit to Nigeria by Anand Sharma, India's Minister of Commerce, in January 2010 it was announced that the state-owned Bharat Heavy Electrics Ltd would be signing an agreement with the Nigerian government to set up three coal-based power projects with a total capacity of 3500 megawatts, involving an investment of US\$2 billion. Furthermore, at the meeting between Anand Sharma and his Nigerian counterpart, Achike Udenwa, the two countries agreed to deepen co-operation in areas such as agriculture, minerals, power and energy, and infrastructure. This was followed by the signing of a defence cooperation agreement in July 2010 (Nigerian High Commission 2013). In the same year, India's Petroleum and Natural Gas Minister met with Emmanuel O Edbogah, special adviser to the Nigerian president, to conclude an agreement that would see Nigeria increase its crude oil supply to India.

One of the most lucrative opportunities which the Indians secured in Nigeria is the US\$6 billion infrastructure deal that ONGC Videsh-Mittal struck with the Nigerian government. This includes the building of a refinery, a power plant and railway lines. In return ONGC Videsh-Mittal will have access to two oil production blocks. A key difference between China and India, with the exception of the role played by ONGC Videsh-Mittal in the oil sector, is the fact that the Indian government is not as active as the Chinese government in promoting the interests of its corporations abroad. To be sure, India's multinational companies operate fairly autonomously from the state. The oil sector is an exception, especially given India's high dependence on oil imports, and the fact that the country's oil companies have a significant public sector shareholding. In contrast to India, the modus operandi of Chinese SOEs reflects strategic guidance or influence by the state.

While Indian companies and the diaspora have long held a presence on the continent, diplomatic involvement has only accelerated in the last few years, culminating in the inaugural India-Africa Forum staged in Delhi in 2008. India has shunned comparisons with China, and emphasised at the time that the Forum was not intended to replicate China's FOCAC. Nevertheless, this move could be 
interpreted as a response from India to China's active engagement with Africa. Indian has also stepped up its engagement with Africa's various regional economic communities, such as the SADC, the Common Market for Eastern and Southern Africa, and the East African Community (Suri 2006:7).

Indeed, relations at the regional level between India and Africa became much more pronounced with the formalisation of the India-Africa Forum. The India-Africa Forum marked the beginning of high-level interactions between the two partners, signalling India's seriousness about deepening diplomatic and commercial relations with Africa. The fact that India shares a common historical experience of colonisation with the African continent, coupled with the existence of its diaspora community in parts of the continent, augurs well for generally smooth diplomatic relations. ${ }^{3}$

In line with the move to expand India's political ambitions in Africa, New Delhi has appealed to a number of strategies such as strengthening South-South cooperation (Mawdsley and McCann 2010:89), promoting multilateralism and South-South solidarity (Taylor 2012:782), dispatching Indian troops to support peace building efforts in Africa (Beri 2008). Given India's strategic interests in Africa, the country's engagement with the continent has gradually shifted from being politically driven to taking on a more pragmatic economic focus, which seeks to "connect the needs of its rapid industrial growth with its global aspirations" (Cheru and Obi 2011:95). India's contemporary foreign policy in Africa combines a desire to promote a just and equitable international order with a yearning to achieve greater influence in global affairs (Taylor 2012:783). Thus, the "current ties between India and Africa can usefully be understood in terms of the pursuit of mutual political and economic cooperation in exchange for increased economic interaction and political support for India's rise on the global stage" (Taylor 2012:794).

Still, the role played by the Indian government in Africa can be characterised as that of selective support, and is most evident in those countries on which India relies the most for oil imports. Here, South Africa is a special case: the country has very deep diplomatic and commercial relations with India, yet it is not an oilproducing country. The strong ties between the two countries can be attributed more to the deep historical and cultural links as well as the diverse nature and size of South Africa's economy. As Africa's most sophisticated and developed economy, South Africa is an important partner for India. There are about 1,15 million citizens of Indian origin in South Africa, making up almost 2,5\% of the population.

3 In East Africa, relations have not been without tensions. The Indian diaspora was driven away in countries such as Uganda and Kenya post-independence as nationalistic sentiments were unleashed by leaders of these countries. Idi Amin was an architect of the expulsion of Indians in Uganda in August 1972, giving them 90 days' notice to leave the country. Discriminatory practices, in particular draconian immigration laws and commercial restrictions, by the Kenyan government in 1968 drove thousands of Indians to Britain. 
In contrast to China and India, Brazil's strategic engagement with Africa has been much more focused and, generally, confined to a few countries. Indeed, due to strong historic, cultural, and linguistic ties (Ford 2013:88; Stolte 2013:63), 74\% of Brazil's total development assistance is provided to the Portuguese-speaking Lusophone African states of Angola, Cape Verde, Guinea-Bissau, Mozambique, and Sao Tome and Principe (He 2012:32). Brazil has engaged with Africa from the standpoint of South-South cooperation and provided technical assistance to African countries with a view to gaining an advantage over the established powers in the battle for influence in Africa (Stolte 2013:66). This, in turn, has helped to raise Brazil's credibility as a leader of the global South, and one that acts in the broad interests of the developing world (Stolte 2013:67). Given its size and the number of votes that African countries carry in international institutions, the African continent is of considerable importance to Brazil, both in terms of its ambition to secure a seat at the UN Security Council and to fulfill its other aims on the international stage (Stolte 2013:66).

In strategic terms, Russia sees its relations with Africa as crucial to its desire to promote a multipolar world and to ensuring that the country is not isolated internationally. To this end Russia has, among other things, participated actively in contributing towards peace and security in Africa, notably through involvement in peacekeeping missions on the continent, including in countries such as the DRC, Liberia and Sudan. Russia also contributes to the AU Fund. In terms of debt relief and development assistance, Russia has alleviated US\$20 billion of African debt in recent years, and has implemented a preferential system for certain African export commodities (Arkhangelskaya and Shubin 2013:19). Moreover, Moscow has concluded a number of agreements on the utilisation of remaining debts to finance development projects.

The advent of the BRICS Development Bank also represents a crucial strategic lever for Russia in Africa. Moscow is keen, for example, to use the conclusion of co-operation agreements, notably on the co-financing of infrastructure projects in Africa, to "encourage Russian companies and research bodies dealing with Africa" (Africa Research Bulletin 2008). Russian businesses that operate overseas, including the ones in Africa, are regarded as instruments of an increasingly forceful Russian foreign policy (Africa Research Bulletin 2008). Within this context, Russia's relationship with South Africa is poised to play a pivotal role. Already, the two countries maintain an active dialogue on a range of international political, economic and diplomatic issues through mechanisms such as the BRICS grouping and the Russia-South Africa Joint Intergovernmental Committee on Trade and Economic Co-operation. 


\section{CONCLUSION}

Contrary to the notions of Third World political and economic solidarity that were fashionable among developing countries in the 1950s and the 1960s, the contemporary era of global diplomacy has witnessed growing and intense political and economic competition not only between developed and developing countries, but also among developing countries. Within this context, this article has argued that national interests, rather than friendships, have been the salient drivers of the growing presence of the BRIC countries in Africa. The BRIC countries are not primarily driven by Africa's development concerns, but are seeking to fulfil their own commercial interests as well as use Africa as an avenue for shoring up their international legitimacy and credibility.

The article has demonstrated that although there are some commonalities in the drivers of the BRIC countries' expansion into Africa, there are also clear divergences and nuances across each of the countries. In this respect, the motivations for each country's involvement with Africa are imbued with a particular history, are evolving rapidly over time, and reflect the complexity of the countries' relationships with African states.

There is no doubt that the BRIC countries, especially China, are redefining and will continue to influence the African continent's global geo-political positioning, while also redrawing its economic landscape. It is hard to predict how relations between these countries and Africa will develop in the future. Yet it is clear that they will be largely shaped not only by the evolving political and economic forces in Africa, but also by the changing international and domestic policy priorities of the BRIC countries.

\section{LIST OF SOURCES}

Adisu, K, T Sharkey and SC Okoroafo 2010. "The impact of Chinese investment in Africa", International Journal of Business and Management 5(9):3-9.

Africa Research Bulletin 2008. Africa Research Bulletin: Economic, Financial and Technical Series 45(8):17972-17973.

Arkhangelskaya, A and V Shubin 2013. "Russia's Africa plicy". In: South African Institute of International Affairs, Occasional Paper 157, September.

Baregu, M 2007. "Tanzania-China relations in historical perspective”. In: G le Pere (ed.), China in Africa: Mercantilist predator or partner in development?. Pretoria: Institute for Global Dialogue/South African Institute of International Affairs. 
Bava, US 2007. "New powers for global change? India's role in the emerging world order". Briefing Paper, Friederich Ebert Stiftung, New Delhi, March.

Beri, R 2003. "India's Africa policy in the Post-Cold War era: An assessment", Strategic Analysis 27(2):216-232.

Beri, R 2008. "India's role in keeping peace in Africa", Strategic Analysis 32(2):197-221.

Brautigam, D 2011. The Dragon's gift: The real story of China in Africa. Reprinted edition, New York: Oxford University Press.

Broadman, HG 2007. Africa's silk road: China and India's new economic frontier. Washington, D.C.: World Bank.

Cheru, F and C Obi 2011. "Chinese and Indian engagement in Africa: Competitive or mutually reinforcing strategies?", Journal of International Affairs 64(2):91-110.

Drummond, P and Xue Liu 2013. "Africa's rising exposure to China: How large are spillovers through trade?” IMF Working Paper WP 13/250, November:1-24.

Ford, N 2013. "Brazil-Africa: Old ties bring new investment", African Business, November:86-88.

Freemantle, S and J Stevens 2010. "CII-Exim Bank Conclave on India Africa Project Partnership confirms thrust of India Inc. in Africa", Standard Bank Research Paper, 17 March.

Ganeshan, S 2012. "India and Africa: Strengthening energy ties and striding towards a strategic partnership", KAS International Reports 4:61-76.

Gottwald, J and N Duggan 2011. "Expectations and adaptation: China's foreign policies in a changing global environment", International Journal of China Studies 2(1):1-26.

He, T 2012. "Back to ABCs: Emerging partnerships among Africa, Brazil, and China”, Harvard International Review 34(1):30-33.

Hofstedt, TA 2009. "China in Africa: An Africom response", Naval War College Review 62(3):79-100.

Hutton, W 2007. The writing is on the wall: China and the West in the $21^{\text {st }}$ century. London: Little Brown. 
International Energy Agency 2007. "China and India insights", World Energy Outlook 2007, <http://iea.org/textbase/nppdf/free/2007/weo_2007.pdf>, accessed 18 September 2015.

Investment Adviser. 2009. "Russia's interest highlights Africa's importance", Investment Adviser, 24 August 2009. Financial Times Ltd.

Jordan, PA 2010. "A bridge between the global North and Africa? Putin's Russia and G8 development commitments", African Studies Quarterly 11(4):83-115.

Kan, K 2013. "Whither Weiwen? Stability maintenance in the 18th Party Congress era", China Perspectives 1:87-93.

Katti, V, T Chahoud and A Kaushik 2009. "India's development cooperation: Opportunities and challenges for international development cooperation". Briefing Paper 3/2009, German Development Institute.

Klomegah, KK 2008. "Russia and China have irreconcilable geopolitical interests in Africa”, Noticias Financieras, 18 June.

Klomegah, KK 2013. "Africa: Russian investment needs credit support", Afrocom 22 July, $<$ http://www.afrocom.ru/en/news/analytics/141>, accessed 22 September 2015.

Konings, P 2007. "China and Africa: Building a strategic partnership", Journal of Developing Societies 23(3):341-367.

Lee, CK and Y Zhang 2013. "The power of instability: Unraveling the microfoundations of bargained authoritarianism in China", American Journal of Sociology 118(6):1475-1508.

Le Pere, G and G Shelton 2006. "Africa-Chinese relations: An evolving SouthSouth partnership", South African Journal of International Affairs 13(1):33-53.

Mandelbaum, M 2014. "BRIC bust?", The American Interest IX(5), May/June, $<$ http://www.the-american-interest.com/articles/2014/04/20/bric-bust/>, accessed 17 September 2015.

Masud, MMH and M Faisal 2013. "Politics of economy: The case of China's involvement in Africa", Journal of Educational and Social Research 3(1):163-168.

Mawdsley, E and G McCann 2010. "The elephant in the corner? Reviewing IndiaAfrica relations in the new millennium", Geography Compass 4(2):81-93. 
Mckinsey Global Institute 2010. "Lions on the move: The progress and potential of African economies", June, <http://www.mckinsey.com/insights/africa/lions_on_ the move>, accessed 27 November 2015.

NDTV Correspondent 2011. "Bharti ready for the next leg with Zain," NDTV, 25 November, <http://profit.ndtv.com/news/market/article-bharti-ready-for-the-nextleg-with-zain-95415>, accessed 18 September 2015.

Nigerian High Commission 2013. "Nigeria - India: A key partnership", <http:// www. nigeriahc.sg/nhc/?pid=114>, accessed 22 September 2015.

People's Daily 2006. China's African policy, white paper. Beijing, People's Republic of China, <http://english.peopledaily.com.cn/200601/12/eng20060112_234894.html>, accessed 17 September 2015.

Pradhan, SK 2012. "India and Africa: Quest for oil and gas", Indian Foreign Affairs Journal 7(3):284-295.

Qobo, M 2010. "Zuma's state visit and the challenges of doing business in Russia", Sunday Independent, 8 August.

Santander, S 2014. "Brazil in Africa: Strategic issues", African Geopolitics 45:59-70.

Stolte, C 2012. Brazil in Africa: Just another BRICS country seeking resources?. Chatham House, London, November.

Stolte, C 2013. "Brazil in Africa: Seeking international status, not resources", Harvard International Review 34(4):63-67.

Sun, Y 2014. Africa in China's foreign policy. Paper prepared for John L. Thornton China Center and Africa Growth Initiative, Brookings, Washington, D.C., April.

Suri, N 2006. "India's foreign policy. India and Africa: a contemporary perspective". South-African-Indian Business Council Meeting, 2 September.

Taylor, I 2012. “India’s rise in Africa", International Affairs 88(4):779-798.

Trevaskes, S 2013. "Rationalizing stability preservation through Mao's not so invisible hand", Journal of Current Chinese Affairs 42(2):51-77.

United Nations 2007. Asian foreign direct investment in Africa: Towards a new era of cooperation among developing countries, <http://unctad.org/en/docs/ iteiia20071_en.pdf>, accessed 17 September 2015. 
Vines, A 2007. “China in Africa: A mixed blessing?”, Current History, May:213-219.

Vines, A et. al. 2009. "Thirst for African oil: Asian National Oil Companies in Nigeria and Angola". Chatham House Report, <https://www.chathamhouse.org/ sites/files/ chathamhouse/r0809_africanoil.pdf>, accessed 22 September 2015.

Walker, R 2014. "What is the investment Big Daddy in Africa?", African Business, March:56-58.

Winton, DW 2013. "Conflict by other means. Economic statecraft: China in Africa”, Parameters 43(4):99-110.

Xinhua 2009. "Senior Chinese officials calls on US to respect China's core national interests", BBC Monitoring Asia Pacific. London, 29 July.

Yates, D 2006. "Chinese oil interests in Africa". In: G le Pere (ed.) China in Africa: Mercantilist predator or partner in development?. Pretoria: Institute for Global Dialogue/South African Institute of International Affairs, pp. 220-238. 